\title{
Procedural effects of prey tethering experiments: predation of juvenile scallops by crabs and sea stars
}

\author{
M. A. Barbeau, R. E. Scheibling \\ Department of Biology, Dalhousie University, Halifax, Nova Scotia, Canada B3H 4J1
}

\begin{abstract}
This study examines the effects of an experimental tethering procedure often used in field predation experiments. In laboratory experiments, juvenile sea scallops Placopecten magellanicus, either free or tethered, were offered to predatory crabs Cancer irroratus and sea stars Asterias vulgaris. The effect of the tethering procedure on predation rates was specific to a predator-prey interaction and could be predicted based on an understanding of the underlying behavioural mechanisms. In crab-scallop interactions, encounter rate was a major determinant of predation rate. Since tethering did not affect encounter rates, it did not significantly affect predation rates by crabs. In contrast, in sea star-scallop interactions, the probability of sea stars capturing encountered scallops was a major determinant of predation rate. Tethering limited the scallops' escape response, which increased the probability of capture and, hence, predation rate. Therefore, assessment of the relative importance of these 2 predators in determining scallop survival in field experiments would be biased by the differential effects of the tethering procedure.
\end{abstract}

KEY WORDS: Asterias vulgaris - Cancer irroratus - Placopecten magellanicus · Predation · Procedural effects · Tethering

Manipulative field experiments have played a major role in demonstrating the importance of biological interactions such as predation and competition in regulating population dynamics and community structure in marine benthic environments (Connell 1975, Dayton \& Oliver 1980, Peterson 1982, Watanabe 1984, Witman 1985). Many experimental studies have used physical barriers, such as caging or tethering, to control densities or movement of animals (Virnstein 1977, Vadas et al. 1986, Heck \& Wilson 1987, Aronson 1989, Prescott 1990, Pohle et al. 1991, Scheibling \& Hamm 1991, Ambrose \& Irlandi 1992, Witman \& Sebens 1992). However, it is generally conceded that these procedures may have artifactual effects which should be controlled or assessed (for caging studies, see Dayton \& Oliver 1980, Hall et al. 1990). Studies involving tethering of prey usually attempt to determine the relative intensity of predation in different situations rather than measure actual predation rates. The advantages of the tethering procedure are that tethered animals can be individually identified and monitored through time, and that the cause of mortality of the individuals can often be determined from the remains. However, the relative importance of different predators on mortality cannot be assessed if tethering affects these predators differently. It is often assumed that if a prey species does not rely on active escape, but on passive escape or crypsis, then the bias introduced by tethering should be minimal. However, this assumption has never been examined experimentally (see Peterson \& Black 1994; this issue), although Barshaw \& Able (1990) demonstrated that tethering of juvenile lobsters Homarus americanus affects their burrowing behaviour, a possible escape mechanism from certain predators.

Predation of juvenile sea scallops Placopecten magellanicus (Gmelin), particularly by crabs and sea stars, appears to be important in limiting population size of this commercially important bivalve species in Atlantic Canada and the northeastern USA (Naidu et al. 1989, Hatcher et al. in press). To examine predation rate and the biological and physical variables that influence it (e.g. prey size, prey and predator density, temperature, habitat), scallops were tethered in field experiments (Barbeau 1994). In this study, we examine the effect of tethering scallops on predation rates by crabs and sea stars in laboratory experiments and identify underlying behavioural mechanisms.

Materials and methods. In July-August 1993, we conducted 2 laboratory experiments in $90 \times 60 \times 50 \mathrm{~cm}$ (length $\times$ width $\times$ height) flow-through seawater tanks to assess the effect of tethering scallops on predation by the rock crab Cancer irroratus Say and the sea star Asterias vulgaris Verrill (= A. rubens Linnaeus; Clark \& Downey 1992). Both species have been observed to be major predators of juvenile sea scallops in the laboratory 
and the field (Medcof \& Bourne 1964, Elner \& Jamieson 1979, Barbeau \& Scheibling 1994, in press, Hatcher et al. in press). Individual predators were offered 15 scallops in each of 2 treatments: tethered or free-ranging prey. Based on previous laboratory experiments examining size-selective predation (Barbeau \& Scheibling 1994), predators were offered their preferred scallop prey size: large juvenile scallops [mean \pm SD: $24.7 \pm 1.8 \mathrm{~mm}$ shell height $(\mathrm{SH})]$ in the crab experiment and small scallops $(10.3 \pm 1.5 \mathrm{~mm} \mathrm{SH})$ in the sea star experiment. (Predation rates were minimal for crabs preying on small juvenile scallops and sea stars preying on large juvenile scallops, which precluded comparisons between predators for similar prey sizes.) There were 3 replicate tanks for each treatment in a completely random design. Two control tanks, one with 15 tethered scallops and the other with 15 free-ranging scallops, but without a predator, were run concurrently to monitor mortality due to causes other than predation. Non-predatory mortality was negligible in both experiments ( 1 free scallop died in the crab experiment). The duration of the experiment was $5 \mathrm{~d}$ and $7 \mathrm{~d}$ for crabs and sea stars, respectively. Experimental tanks were monitored daily in the morning and just before sunset to record the number of scallops consumed and to replace consumed scallops. Predation rate was calculated for each predator as the total number of scallops consumed by the particular predator during the experiment divided by the duration (in days) of the experiment.

Rock crabs [ $86 \pm 7 \mathrm{~mm}$ carapace width (CW)] were collected from East Point Gut, Lunenburg Bay, Nova Scotia, and sea stars (100 $\pm 12 \mathrm{~mm}$ diameter) from Mill Cove, St. Margaret's Bay, Nova Scotia. Prior to experiments, predators were held in tanks with flowing ambient seawater for 3 to $4 \mathrm{wk}$ and fed live, intact mussels Mytilus edulis ad libitum. Before initiation of experiments, predators were starved for $24 \mathrm{~h}$. Only male crabs were used to avoid potential confounding sex-related variation. Juvenile scallops were obtained from spat collectors in Passamaquoddy Bay, New Brunswick, through a commercial supplier (The Great Maritime Scallop Trading Co.). Prior to experiments, scallops were held in tanks with flowing ambient seawater for 1 to $2 \mathrm{wk}$. Prior to and during experiments, scallops were continually drip-fed to maintain $\sim 1 \times$ $10^{4}$ cells $\mathrm{ml}^{-1}$ of cultured algae, T-Isochrysis galbana or Thalassiosira pseudonana. Ambient seawater was sandbed-filtered to $50 \mu \mathrm{m}$, and the flow to each experimental tank regulated at $900 \pm 200 \mathrm{ml} \mathrm{min}^{-1}$ (mean \pm $\mathrm{SD}$ ). Water temperature measured twice daily was $10.7 \pm 0.8^{\circ} \mathrm{C}$ and $13.9 \pm 0.4^{\circ} \mathrm{C}$ over the duration of the $\mathrm{crab}$ and sea star experiments, respectively. Lighting was by overhead fluorescent lights and natural light through windows. The natural light:dark regime was maintained in both experiments.
The tethering procedure was similar to that used in previous field experiments (Barbeau 1994, Hatcher et al. in press). A small area of the upper valve of a scallop was cleaned with a cotton swab and acetone (care was taken not to exposed the scallop's mantle edge to acetone) and dried with an airjet. One end of a 20 to 25 $\mathrm{cm}$ long monofilament line (Berkley Trilene XL, $8 \mathrm{lb}$ ) was glued to this valve using cyanoacrylate glue, and the other end was tied to a stainless steel stake $(12 \mathrm{~cm}$ length, $0.5 \mathrm{~cm}$ diameter) with a numbered tag (used to anchor and individually identify tethered scallops in the field). The effective tether length was $17 \pm 1 \mathrm{~cm}$ (mean \pm SD) after gluing and tying. A preliminary laboratory experiment with varying tether lengths $(5,10$, $15 \mathrm{~cm}$ ) showed that predation rates on scallops by sea stars decreased by $\sim 30 \%$ from 5 to $10 \mathrm{~cm}$ tether length, but were similar between 10 and $15 \mathrm{~cm}$ tether length. Scallops were tethered and held in a separate tank at least $24 \mathrm{~h}$ before being placed on the bottom of the experimental tanks. To maintain a similar bottom type in the treatment with either free or tethered scallops, stakes were also placed in the tanks with free scallops

To identify behavioural mechanisms underlying observed predation rates, predators and scallops were observed for 20 to $30 \mathrm{~min}$ periods at randomly chosen times in daytime. We did not detect differences between daytime and nighttime behaviours of crabs, sea stars and scallops during $24 \mathrm{~h}$ video monitoring of previous experiments (Barbeau \& Scheibling in press). Total observation times were 420 and 510 min tank $^{-1}$ for the crab and sea star experiments, respectively. Measurements based on these observations included: (1) percentage of time that predators spent searching for scallops, i.e. (searching time/observation time) $\times 100$; (2) percentage of time that predators spent handling scallops, i.e. (handling time/observation time) $\times 100$; (3) encounter rate between predators and scallops during searching time, i.e. number of encounters/searching time; (4) probability of capture upon encounter, i.e. (number of rejections + consumptions)/number of encounters; (5) probability of consumption upon capture, i.e. number of consumptions/(number of rejections + consumptions); and (6) the ratio of scallop active escapes to total escapes, i.e. (number of swims + jumps)/(number of swims + jumps + non-mobile escapes). Non-mobile escapes occurred when scallops closed their valves and avoided capture by crabs and when sea stars retracted from scallops. Additional measurements in the sea star experiment were: (1) proportion of active escapes resulting in swims, i.e. number of swims/(number of swims + jumps); (2) proportion of active escapes resulting in collision with tank wall, i.e. number of collisions/(number of swims + jumps); and (3) proportion of active escapes hindered by tether, i.e. number of hindrances/(number of swims 
+ jumps). See Barbeau \& Scheibling (1994) for a detailed description of the different behaviours.

Predation rates and other measurements of behaviour were compared between treatments (free and tethered scallops), and the probability of consumption was compared to 1 , using 2 -tailed $t$-tests, after verifying for homogeneity of variance using Cochran's test. Heteroscedasticity was significant in 1 case only (sea star predation rate), and log-transformation was successful in homogenizing the variance.

Results. The predation rate on tethered scallops by crabs Cancer irroratus did not differ significantly from that on free scallops ( $t=1.87, \mathrm{df}=4, \mathrm{p}>0.10$; Fig. 1a), although our analysis could only detect large differences between treatments $(\delta=1.4$, power $=0.3$; Winer 1971). The percentages of time that crabs spent searching for and handling scallops were very low (Fig. $1 \mathrm{~b}$ ) and not significantly affected by tethering $(t=$ 1.28 and 1.13 , respectively, $\mathrm{df}=4, \mathrm{p}>0.20$ ). Encounter rates between crabs and scallops were high (Fig. 1c) and also not significantly affected by tethering $(t=$ 0.66 , $\mathrm{df}=4, \mathrm{p}>0.50$ ). The probability of capture upon encounter was similar for free scallops (mean $\pm \mathrm{SE}$ : $0.56 \pm 0.15)$ and tethered scallops $(0.64 \pm 0.18)(t=0.37$. $\mathrm{df}=4, \mathrm{p}>0.50$ ). The probability of consumption upon capture did not differ significantly from 1 for either group (free scallops: $1.00 \pm 0.00$; tethered scallops: 0.77 $\pm 0.15, t=-1.60, \mathrm{df}=2, \mathrm{p}>0.20$ ). Although rejection of free scallops by crabs was not observed in this study, it has been observed in previous studies (Barbeau \& Scheibling 1994, in press). Active escapes from crabs represented $52 \pm 20 \%$ of total escapes for tethered and free scallops combined.

Sea stars Asterias vulgaris consumed 16.7 times more tethered scallops than free scallops (log-transformed data, $t=3.92$, df $=4, \mathrm{p}<0.05$; Fig. 2a). The percentage time that sea stars spent searching for scallops was not significantly affected by tethering $(t=0.52, \mathrm{df}=4, \mathrm{p}>0.50$; Fig. 2b). However, sea stars offered tethered scallops tended to spend more time handling scallops (which included extraoral digestion) than those offered free scallops $(t=2.77$, df $=4$, $p=0.05$ ), due to the higher predation rate on tethered scallops. Encounter rate between sea stars and scallops was not significantly affected by tethering $(t=0.16, \mathrm{df}=4, \mathrm{p}>0.50$; Fig. $2 \mathrm{c})$. However, the probability of capture upon encounter was 13.1 times lower for free scallops $(0.016 \pm 0.009)$ than for tethered scallops $(0.209 \pm 0.052)(t=3.65, \mathrm{df}=4, \mathrm{p}<$ $0.05)$. The probability of consumption upon capture was similar for free scallops $(0.75 \pm 0.25$; no captures were observed for one sea star) and tethered scallops $(0.82 \pm 0.10)(t=0.32, \mathrm{df}=3, \mathrm{p}>0.50)$, and did not differ significantly from $1(-1.8<t<-1$, df $=1$ or 2 , $p>0.20$ ). Most encounters resulted in active escapes
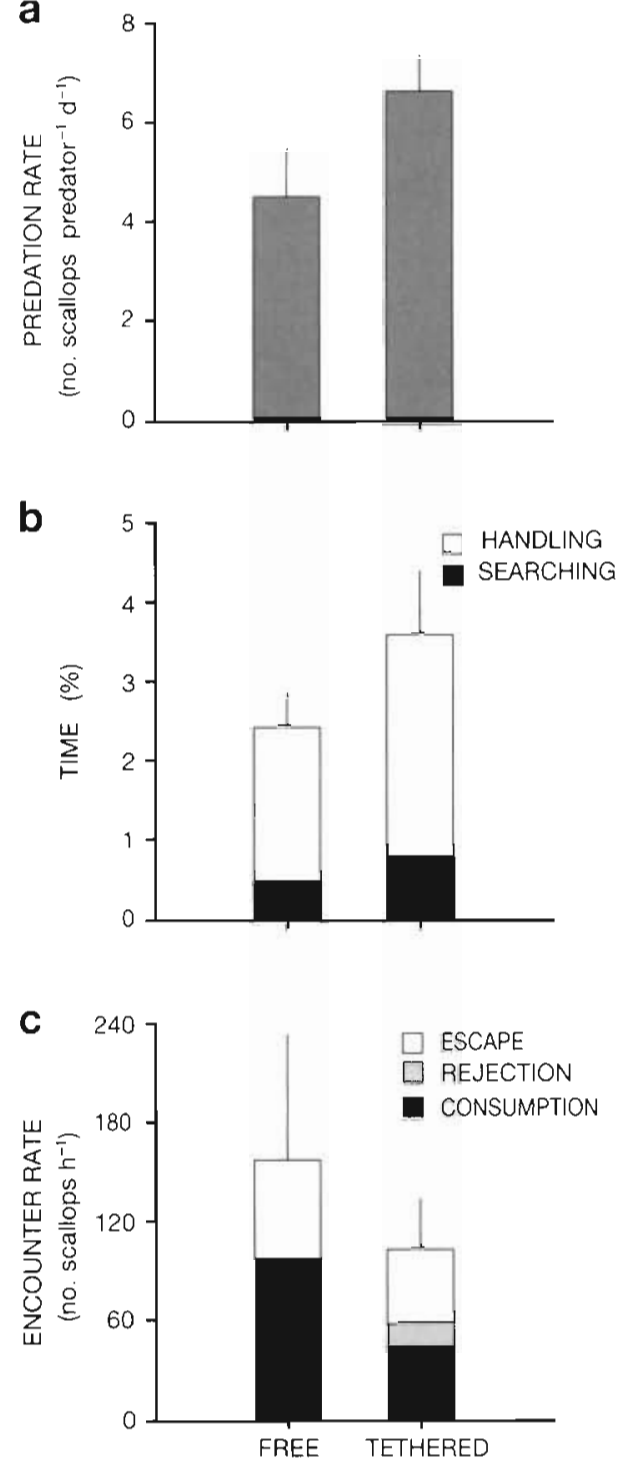

Fig. 1. Laboratory experiment examining the effect of tethering scallops Placopecten magellanicus on predation by crabs Cancer irroratus. (a) Predation rate per crab, (b) percent foraging time (foraging time = searching time + handling time) of crabs, and (c) encounter rate between crabs and scallops (different outcomes of encounter have different shadings). The probability of capture upon encounter was calculated as (number of consumptions + rejections)/number of encounters, and the probability of consumption upon capture as number of consumptions/(number of consumptions + rejections). Crabs were offered either free or tethered scallops. Observation time in (b) and (c) $=420$ min tank $^{-1}$ Mean shown for all variates, error bars = SE [for foraging time in (b) and for encounter rate in (c)], and $n=3$

(Fig. 2c). Retractions from scallops by sea stars accounted for only $13 \%$ total escapes. The ratio of active escapes to total escapes was not significantly affected by tethering ( $t=0.05$, df $=4, \mathrm{p}>0.90$ ). Scallops tended to actively escape from sea stars by jumping (single valve claps displacing scallops along 

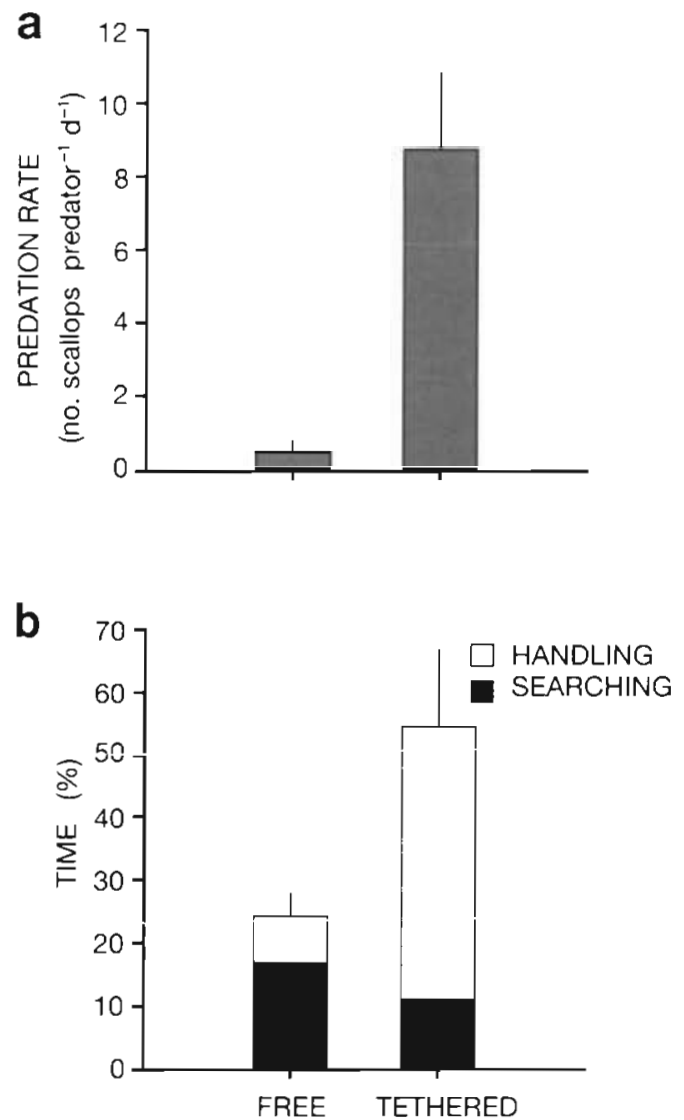
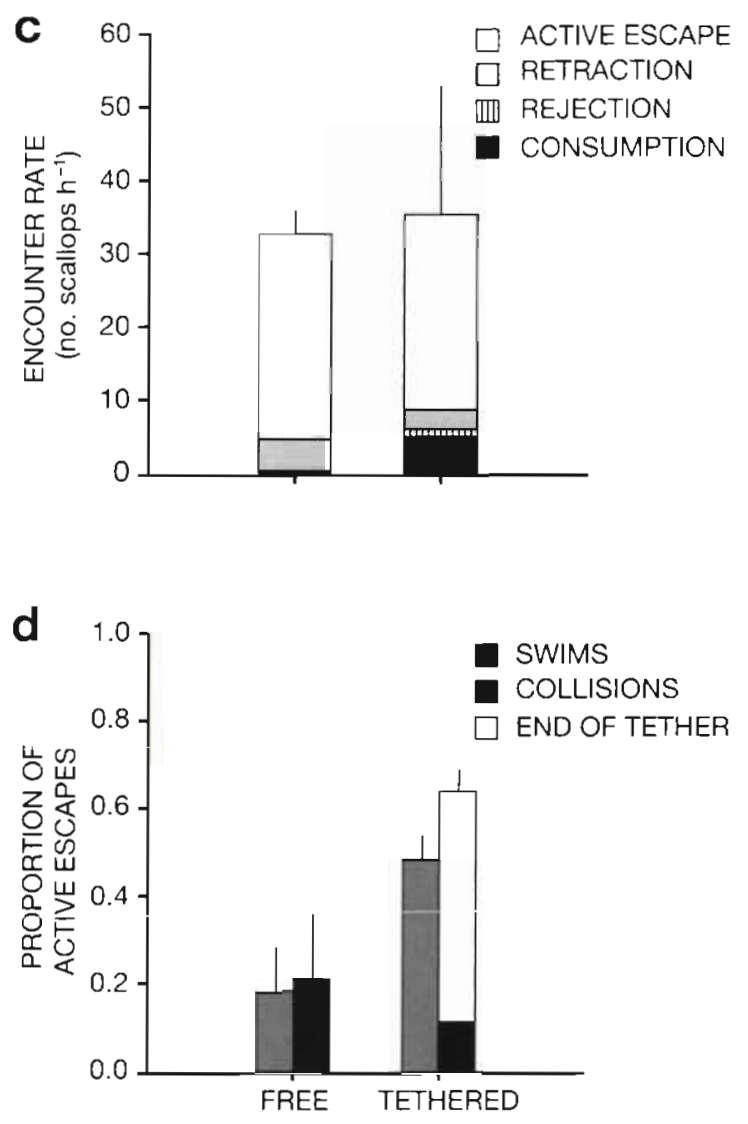

Fig. 2. Laboratory experiment examining the effect of tethering scallops Placopecten magellanicus on predation by sea stars Asterias vulgaris. (a) Predation rate per sea star, (b) percent foraging time (foraging time = searching time + handling time) of sea stars, (c) encounter rate between sea stars and scallops (different outcomes of encounter have different shadings), and (d) proportion of active escapes in which scallops swam (active escapes = swims + jumps) and in which scallops collided with the tank walls or reached the end of their tether. The probability of capture upon encounter was calculated as (number of consumptions + rejections)/number of encounters, and the probability of consumption upon capture as number of consumptions/(number of consumptions + rejections). In (c) the numbers of free scallops rejected and consumed are 0.1 and $0.4 \mathrm{scallops} \mathrm{h}^{-1}$, respectively. Sea stars were offered either free or tethered scallops. Observation time in (b). (c) and (d) $=510$ min tank $^{-1}$. Mean shown for all variates, error bars $=\mathrm{SE}$ [for foraging time in (b) and for encounter rate in (c)], and $n=3$

the bottom) more often than swimming (repeated claps propelling scallops through the water column) (Fig. 2d). The proportion of active escapes by swimming tended to be greater for tethered scallops than for free scallops, although the difference was marginally non-significant $(t=2.57$, df $=4, p=0.06$ ). Collisions with tank walls occurred in $<25 \%$ of active escapes (Fig. 2d) and this was not significantly affected by tethering $(t=0.67$, $\mathrm{df}=4, \mathrm{p}>0.50)$. Tethered scallops reached the end of their tether in $53 \pm 7 \%$ of active escapes (Fig 2d).

Discussion. Tethering had a much greater effect on scallop mortality due to sea star predation than that due to crab predation. The reason for this difference lies in the behavioural mechanisms underlying predation rate (O'Brien 1987, Osenberg \& Mittelbach 1989, Barbeau \& Scheibling 1994, in press). In crab-scallop interactions, encounter rate appears to be a major determinant of predation rate (Barbeau \& Scheibling 1994). Once encountered, juvenile scallops often close their valves, and are likely to be captured and consumed by crabs. Since tethering did not significantly affect encounter rate between scallops and crabs, it did not significantly affect predation rate by crabs.

In sea star-scallop interactions, the probability of capture upon encounter, rather than encounter rate, is a major determinant of predation rate, since scallops readily escape from sea stars by swimming or jumping (Barbeau \& Scheibling 1994). Peterson et al. (1982) also showed that scallops Argopecten irradians use swimming behaviour to escape slow-moving gastropod predators (Busycon carica). In our study, the probability of sea stars capturing free scallops was very low (<0.1) and similar to that observed in previous studies (Barbeau \& Scheibling 1994, in press). The probability of sea stars capturing tethered scallops was much 
higher, since the tether limited active escape. Thus, the higher predation rate by sea stars on tethered than on free scallops was due to the increase in probability of capture. Other studies examining predator-prey interactions in which the prey had an active escape response also have shown that predation rates are limited by the predator's ability to capture prey (Harrold 1982, Sih \& Moore 1990).

This study shows that tethering can have differential effects on predation rates by different predators. Unless a reliable adjustment coefficient is used, it would be difficult to assess the relative importance of crab and sea star predation on scallop mortality in the field. For most field tethering experiments, which usually consist of deploying tethered animals and retrieving them after a few hours or days, frequencies or proportions of animals alive or dead at the end of the experiment are analyzed using contingency tables or analyses of variance (Heck \& Thoman 1981, Watanabe 1984, Heck \& Wilson 1987, Aronson 1989, Prescott 1990, Wilson et al. 1990, Heck \& Hambrook 1991, Pohle et al. 1991). If the proportion of animals alive is monitored over time, then the proportion surviving at each sampling time is not independent, and a repeated measures analysis of variance (with time as the repeated factor) may be used (Crowder \& Hand 1990), or the survival curves may be characterized and statistically compared (e.g. Witman \& Sebens 1992). Either all of the causes of mortality are combined in these analyses or certain causes are excluded. If all causes of mortality are combined, then the measure of predation intensity may be biased due to differential effects of tethering on different causes of mortality. If some causes of mortality are excluded from analysis, then useful information is lost. For example, some tethered animals may be alive and under observation for part of the experiment and then disappear without leaving any clues as to whether they were preyed upon or detached from their tether. The knowledge that these animals were alive for part of the experiment is useful information that is often excluded from analysis. Alternatively, if tethered animals are monitored regularly, individual survival times can be used rather than the proportion of total animals alive at each sampling time (e.g. Minello 1993). Such data can be examined through Survival Analysis (Lawless 1982, Muenchow 1986). Survival Analysis allows separate examination, without excluding data (through a procedure termed 'censoring'), of competing causes of mortality (e.g. crab and sea star predation). Such an analysis would not assess the relative importance of different causes of mortality of tethered animals, but would allow one to assess the effect of covariates (e.g. size, predator and prey density, temperature, habitat) measured during the individual lifetimes on each cause of mortality.
Acknowledgements. We thank $G$. Feltham for assistance in preliminary tethering experiments, and B. G. Hatcher, C. H. Peterson, and an anonymous reviewer for comments on the manuscript. We also thank $W$. Blanchard of the Statistical Consulting Service of Dalhousie University for consultation on survival analysis. M.A.B. was supported by a Natural Sciences and Engineering Research Council of Canada (NSERC) Postgraduate Scholarship, a 'Fonds pour la Formation de Chercheurs et l'Aide à la Recherche' (FCAR, Quebec) Postgraduate Scholarship and an lzaak Walton Killam Memorial Scholarship. The research was funded by an NSERC Operating Grant and an NSERC Networks of Centres of Excellence Grant (Ocean Production Enhancement Network) to R.E.S.

\section{LITERATURE CITED}

Ambrose, W. G. Jr, Irlandi, E. A. (1992). Height of attachment on seagrass leads to trade-off between growth and survival in the bay scallop Argopecten irradians. Mar. Ecol. Prog. Ser. 90: 45-51

Aronson, R. B. (1989). Brittlestar beds: low-predation anachronisms in the British Isles. Ecology 70: 856-865

Barbeau, M. A. (1994). Predator-prey interactions between juvenile sea scallops (Placopecten magellanicus) and predatory sea stars (Asterias sp.) and crabs (Cancer irroratus). Ph.D. thesis, Dalhousie University, Halifax, N.S.

Barbeau, M. A., Scheibling, R. E. (1994). Behavioral mechanisms of prey size selection by sea stars (Asterias vulgaris Verrill) and crabs (Cancer irroratus Say) preying on juvenile sea scallops (Placopecten magellanicus (Gmelin)). J. exp. mar. Biol. Ecol. 180: 103-106

Barbeau, M. A., Scheibling, R. E. (in press). Temperature effects on predation of juvenile sea scallops (Placopecten magellanicus (Gmelin)) by sea stars (Asterias vulgaris Verrill) and crabs (Cancer irroratus Say). J. exp. mar. Biol. Ecol.

Barshaw, D. E., Able, K. W. (1990). Tethering as a technique for assessing predation rates in different habitats: an evaluation using juvenile lobsters Homarus americanus Fish. Bull. U.S. 88: 415-417

Clark, A. M., Downey, M. E. (1992). Starfishes of the Atlantic. Chapman \& Hall, London

Connell, J. H. (1975). Some mechanisms producing structure in natural communities: a model and evidence from field experiments. In: Cody, M. L., Diamond, J. M. (eds.) Ecology and evolution of communities. Belknap Press of Harvard University Press, Cambridge, MA, p. 460-490

Crowder, M. J., Hand, D. J. (1990). Analysis of repeated measures. Chapman \& Hall, London

Dayton, P. K., Oliver, J. S. (1980). An evaluation of experimental analyses of population and community patterns in benthic marine environments. In: Tenore, K. R., Coull, B. C. (eds.) Marine benthic dynamics. University of South Carolina Press, Columbia, p. 93-120

Elner, R. W. Jamieson, G. S. (1979). Predation of sea scallops, Placopecten magellanicus, by the rock crab, Cancer irroratus, and the American lobster, Homarus americanus. J. Fish. Res. Bd Can. 36: 537-543

Hall, S. J., Raffaelli, D., Turrell, W. R. (1990). Predator-caging experiments in marine systems: a reexamination of their value. Am. Nat. 136: 657-672

Harrold, C. (1982). Escape responses and prey availability in a kelp forest predator-prey system. Am. Nat. 119 $132-135$

Hatcher, B. G., Scheibling, R. E., Barbeau, M. A., Taylor, L. H. Hennigar, A. W., Windust, A. (in press). Mortality and dis- 
persion of juvenile sea scallops (Placopecten magellanicus) seeded in a tidal channel. Can. J. Fish. Aquat. Sci.

Heck, K. L. Jr, Hambrook, J. A. (1991). Intraspecific interactions and risk of predation for Dyspanopeus sayi (Decapoda: Xanthidae) living on polychaete (Filograna implexa Serpulidae) colonies. P.S.Z.N. I: Mar. Ecol. 12: 243-250

Heck, K. L. Jr, Thoman, T. A. (1981). Experiments on predator-prey interactions in vegetated aquatic habitats. $J$. exp. mar. Biol. Ecol. 53: 125-134

Heck, K. L. Jr, Wilson, K. A. (1987). Predation rates on decapod crustaceans in latitudinally separated seagrass communities: a study of spatial and temporal variation using tethering techniques. J. exp. mar. Biol. Ecol. 107: 87-100

Lawless, J. F. (1982). Statistical models and methods for lifetime data. John Wiley \& Sons, New York

Medcof, J. C., Bourne, N. (1964). Causes of mortality of the sea scallop, Placopecten magellanicus. Proc. Natl Shellfish. Ass. 53: 33-50

Minello. T. J. (1993). Chronographic tethering: a technique for measuring prey survival time and testing predation pressure in aquatic habitats. Mar. Ecol. Prog. Ser. 101: 99-104

Muenchow, G. (1986). Ecological use of failure time analysis. Ecology 67: 246-250

Naidu, K. S., Fournier, R., Marsot, P., Worms, J. (1989). Culture of the sea scallop, Placopecten magellanicus: opportunities and constraints. In: Boghen, A. D. (ed.) Cold-water aquaculture in Atlantic Canada. The Canadian Institute for Research on Regional Development. Moncton, New Brunswick, p. 211-239

O'Brien, W. J. (1987). Planktivory by freshwater fish: thrust and parry in the pelagia. In: Kerfoot, W. C., Sih, A. (eds.) Predation: direct and indirect impacts on aquatic communities. University Press of New England, Hanover, NH, p. 3-16

Osenberg, C. W., Mittelbach, G. G. (1989). Effects of body size on the predator-prey interaction between pumpkinseed sunfish and gastropods. Ecol. Monogr. 59: 405-432

Peterson, C. H. (1982). The importance of predation and intraand interspecific competition in the population biology of two infaunal suspension-feeding bivalves, Protothaca staminea and Chione undatella. Ecol. Monogr. 52: 437-475

Peterson, C. H., Ambrose, W. G. Jr, Hunt, J. H. (1982). A field test of the swimming response of the bay scallop (Argopecten irradians) to changing biological factors. Bull. mar.

This note was presented by R. N. Hughes (Senior Editoral Advisor), Bangor, UK
Sci. 32: 939-944

Peterson, C. H., Black, R. (1994). An experimentalist's challenge: when artifacts of intervention interact with treatments. Mar. Ecol. Prog. Ser. 111: 289-297

Pohle, D. G., Bricelj, V. M., Garcia-Esquivel, Z. (1991). The eelgrass canopy: an above-bottom refuge from benthic predators for juvenile bay scallops Argopecten irradians. Mar. Ecol. Prog. Ser. 74: 47-59

Prescott, R. C. (1990). Sources of predatory mortality in the bay scallop Argopecten irradians (Lamarck): interactions with seagrass and epibiotic coverage. J. exp. mar. Biol. Ecol. 144: 63-83

Scheibling, R. E., Hamm, J. (1991). Interactions between sea urchins (Strongylocentrotus droebachiensis) and their predators in field and laboratory experiments. Mar. Biol. 110: $105-116$

Sih, A., Moore, R. D. (1990). Interacting effects of predator and prey behaviour in determining diets. In: Hughes, R. N (ed.) Behavioural mechanisms of food selection. SpringerVerlag. New York, p. $771-796$

Vadas, R. L., Elner, R. W., Garwood, P. E., Babb, I. G. (1986). Experimental evaluation of aggregation behavior in the sea urchin Strongylocentrotus doebachiensis: a reinterpretation. Mar. Biol. 90: 433-448

Virnstein, R. W. (1977). The importance of predation by crabs and fishes on benthic infauna in Chesapeake Bay. Ecology 58: $1199-1217$

Watanabe, J. M. (1984). The influence of recruitment, coulpetition, and benthic predation on spatial distributions of three species of kelp forest gastropods (Trochidae: Tegula). Ecology 65: 920-936

Wilson, K. A., Able, K. W., Heck, K. L. Jr (1990). Predation rates on juvenile blue crabs in estuarine nursery habitats: evidence for the importance of macroalgae (Ulva lactuca). Mar. Ecol. Prog. Ser. 58: 243-251

Winer, B. J. (1971). Statistical principles in experimental design. McGraw-Hill, New York

Witman, J. D. (1985). Refuges, biological disturbance, and rocky subtidal community structure in New England. Ecol. Monogr. 55: 421-445

Witman, J. D., Sebens, K. P. (1992). Regional variation in fish predation intensity: a historical perspective in the Gulf of Maine. Oecologia 90: 305-315

Manuscript first received: February 14, 1994

Revised version accepted: May 13, 1994 